\title{
РУССКИЙ ИНТЕЛЛИГЕНТ В ЭПОХУ СОЦИАЛЬНЫХ ПОТРЯСЕНИЙ: Н.С. КАРИНСКИЙ (1873-1949) ${ }^{1}$
}

\section{RUSSIAN INTELLECTUAL IN THE ERA OF SOCIAL UPHEAVALS: \\ N.S. KARINSKY (1873-1949)}

\section{P. Akulshin}

Summary: For the first time in Russian historiography, the article examines the life and work of Nikolai Sergeyevich Karinsky (1873-1949), a prominent lawyer of the pre-revolutionary era who played a significant role in the events of 1917 and the Russian Civil war. In exile, he created an extensive memoir legacy, which has not yet been introduced into scientific circulation.

Keywords: Russia of the beginning of the XX century, revolution of 1917, Russian Diaspora, intellectuals, cadet party, memoirs.

\author{
Акульшин Петр Владимирович \\ Д.и.н., профессор, Рязанский государственный \\ университет имени С.А. Есенина \\ stone2708@mail.ru
}

Аннотация: В статье впервые в отечественной историографии рассматривается жизнь и деятельность Николая Сергеевича Каринского (1873-1949), видного юриста дореволюционной эпохи, сыгравшего заметную роль в событиях 1917 г. и Гражданской войне в России. В эмиграции он создал обширное мемуарное наследие, которое до сих пор не введено в научный оборот.

Ключевые слова: история России начала XX в., революция 1917 г., Гражданская война, Русское Зарубежье, интеллигенция, партия кадетов, воспоминания.

дебной палаты, а затем Харьковской судебной палаты, в округ которой входила Орловская губерния [6]. По свидетельству мемуаристов в Орле он принимал активное участие в деятельности социал-демократических кружков, а его квартира была местом тайных собраний и издания подпольных прокламаций $[3,12,25]$.

Летом 1905 г. Каринский переехал в Харьков, охваченный бурными революционными событиями юга России. К этому времени ему было присвоено звание присяжного поверенного, что позволяло начать самостоятельную адвокатскую практику. Надо отметить, что достигший возраста Христа юрист совмещал активную общественную деятельность с устройством личной жизни. Еще в Москве он женился на Н.Г. Браун - дочери проживавшего в Москве французского купца. Наличие трех детей от этого брака не помешало разводу и женитьбе в Орле на дочери местного купца. Второй брак также не был ни удачным, ни продолжительным, однако он так и не был расторгнут по законам Российской империи на протяжении последующих десятилетий. В Харькове Каринский связал свою судьбу с дочерью местного миллионера А.Я. Жмудского, Варварой Андреевной [6]. Это позволило Каринскому войти в один из богатейших кланов харьковской буржуазии.

К этому времени он уже завоевал репутацию успешного адвоката, который брался за самые сложные уго-

Исследование выполнено при финансовой поддержке РФФИ в рамках научного проекта № 20-09-00164 
ловные и гражданские дела. Так, в 1910 г. он добился оправдания в Харьковском окружном суде судебного следователя Тер-Семенова, застрелившего в пылу ссоры свою жену, мать четырехлетней дочери [11]. Каринский небезуспешно вел и политические дела, не боясь вступать в конфликт с судебными и административными властями [2]. Одним из направлений его деятельности была защита сектантов, преследуемых властями и православной церковью. Известный деятель РСДРП В.Д. БончБруевич так вспоминал о Каринском: «Мне в качестве эксперта с ним приходилось очень много раз выступать на судебных процессах по сектантским делам, и он всегда вел эти процессы очень умело, энергично, со знанием дела и настолько свободно, что его речи и допросы миссионеров, священников и всех шпионов православного ведомства нередко вызывали протесты прокурора и председателя суда» [1].

Свидетельством признания Каринского в среде адвокатуры Юга России стало его избрание 9 декабря 1907 г. членом Совета присяжных поверенных округа Харьковской судебной палаты, руководящего выборного органа этой немногочисленной элитарной корпорации. Переизбирался Каринский в этом качестве и на протяжении последующих восьми лет [13-23]. Он не был чужд и журналистской деятельности, публикуя свои корреспонденции в столичных газетах либерального направления (московской газете «Русское слово» и петербургском еженедельнике «Право»); активно сотрудничал и в харьковской газеты «Утро», которую издавал брат его жены присяжный поверенный А.А. Жмудский. К этому времени марксистские увлечения молодости прошли, и Каринский в Харькове стал одним из респектабельных представителей местной либеральной общественности, членом Харьковского комитета партии кадетов, состоял он и выборщиком от Харькова во ІІ Государственную думу [6].

В 1915 г. Каринский с новой супругой возвратился в Москву, которую покинул почти двадцать лет тому назад. Преуспевающий адвокат из провинции, имеющий большие связи в либеральных кругах, становится членом Московского комитета партии кадетов, уполномоченным Всероссийского земского союза и товарищем председателя Московского Комитета помощи беженцам и эвакуированным с театра военных действий во время Великой войны [6]. Падение монархии весной 1917 г. открывало перед энергичным адвокатом, как и перед другими либерально настроенными представителями «свободных профессий», большие карьерные перспективы на государственной службе. В дни Февральской революции в старой столице он стал одним из комиссаров Московского градоначальства. В марте 1917 г. Каринский был включен в состав учрежденной Временным правительством «Чрезвычайной следственной комиссии для расследования противозаконных по должности действий бывших министров, главноуправляющих и прочих высших должностных лиц...» для осуществления прокурорского надзора за следствием. Следующим шагом в его стремительной карьере стало назначение 15 мая 1917 г. прокурором Петроградской судебной палаты, в качестве которого он сменил ставшего министром юстиции первого коалиционного Временного правительства П.Н. Переверзева [5].

В ходе трехмесячного пребывания в этой должности Каринский выступил в роли одного из активных деятелей на поприще борьбы с растущим в столице революционным движением. Вместе с начальником контрразведки штаба Петроградского военного округа Б.Н. Никитиным, который называл его в своих мемуарах «энергичным прокурором», Каринский руководил операцией по очистке от анархистов дачи бывшего министра П.Н. Дурново, которая была одной из первых попыток Временного правительства применить силу против своих радикальных противников [10]. Не менее важную роль он сыграл и в дни июльского кризиса 1917 г. По решению Временного правительства 7 июля ему было передано расследование организации вооруженного выступления против государственной власти, и он возглавил Особую следственную комиссию [26, 30, 32, 33]. На основании этого постановления Каринский подписал ордер на арест руководителей июльского выступления и привлечение их к судебной ответственности по ст. 51, 100 и 108 Уголовного положения как виновных в измене родине, революции и организации вооруженного восстания. Этот список возглавлял лидер РСДРП (б) В.И. Ленин.

Первым итогом расследования стало сообщения прокурора Петроградской судебной палаты для печати от 22 июля 1917 г. В нем говорилось о том, что комиссией собраны неопровержимые доказательства организации и руководства вооруженным выступлением Центральным Комитетом РСДРП (б), а обвиняемые во главе с Владимиром Ульяновым (Лениным) вошли в соглашение с агентами находящихся в войне с Россией государств в целях дезорганизации армии и тыла, организовав на полученные от этих государств денежные средства пропаганду немедленного отказа от военных действий и выступления против власти, сопровождавшиеся убийствами и насилием, а также попытками ареста членов правительства.

С кипучей антибольшевистской деятельностью Каринского в июльские дни связан загадочный эпизод, требующий дополнительного изучения. Входивший в ближайшее окружение вождя большевиков В.Д. БончБруевич в своих мемуарах сообщил о том, что важную роль в спасении В.И. Ленина от готовящегося ареста сыграл неожиданный телефонный звонок 4 июля 1917 г. В изложении большевика-мемуариста произошло следу- 
ющее: «Я звоню к вам, - сказал он мне (звонивший В.Д. Бонч-Бруевичу - П.А.), - чтобы предупредить вас: против Ленина здесь собирают всякие документы и хотят его скомпрометировать политически. Я знаю, что вы с ним близки. - В чем же дело? - спросил я его. - Ленина обвиняют в шпионаже в пользу немцев. - Но вы понимаете, что это самая гнусная из клевет? - ответил я ему. - Как я это понимаю, в данном случае все равно. На основе этих документов будут преследовать его и всех его друзей. Преследование начнется немедленно. Я говорю это серьезно, и прошу вас немедленно же принять серьезные меры, - сказал он как-то глухо, торопясь. - Все это я сообщаю вам в знак нашей старинной дружбы. Более я ничего не могу вам сказать! Действуйте... - По тону разговора я понял, что Каринский спешил, ибо ему, ввиду его служебного положения, было опасно мне все это сообщать» [1].

Сам Каринский, находясь в эмиграции, полностью отвергал возможность подобного звонка. В.Д. БончБруевич в связи с этим в 1924 г. прокомментировал: «Мне стало известно, что Н.С. Каринский в Нью-Йорке негодует на мою совершенно правдивую, почти стенографическую запись, замечательного разговора. Ему я рекомендовал бы задуматься лишь над одним: за его официальную деятельность в правительстве Керенского он, несомненно, подлежал расстрелу по суровым законам диктатуры пролетариата и кровавой гражданской войны. Он был всецело в наших руках и даже был принят мною в Кремле. Почему же он не был арестован, почему ему было разрешено большевистской властью выехать из Москвы на Украину? Только потому, что его явная заслуга по предупреждению ареста Владимира Ильича была с благодарностью учтена советской властью и к его просьбе отнеслись, в силу этого, дружелюбно. Большевики за добро всегда платят добром» [1].

Аргументы В.Д. Бонч-Бруевич представляются достаточно убедительными, хотя еще предстоит разобраться, настолько достоверным является этот любопытный эпизод. Если такой звонок действительно имел место, то, что за ним скрывалось? Личная инициатива прокурора или тонкая, но не доведенная до удачного завершения интрига Временного правительства? Так или иначе, работа комиссии Каринского по расследованию антиправительственного выступления 4-6 июля в связи с быстрой сменой политической конъюнктуры в стране уже в августе фактически прекратилась. Сам он 21 августа был назначен старшим председателем Петербургской судебной палаты, а через четыре дня был уволен и с этой должности [6].

После Октября 1917 г. Каринский не предпринимал никаких попыток сотрудничества с Советской властью. Он перебрался в Москву, а затем принял решение о выезде с территории РСФСР, для чего у него было фор- мальные основания как у гражданина Украины, провозгласившей при помощи германских интервентов свою независимость. Каринский и здесь активно участвовал в различного рода политических комбинациях, будучи товарищем председателя Харьковского комитета «Союза Возрождения России» [6]. По свидетельству одного из мемуаристов, осенью 1918 г. в Киеве в момент эвакуации германских войск и падения власти гетмана П.П. Скоропадского бывшего прокурора в некоторых кругах даже именовали претендентом на роль «русского Наполеона», которому якобы только нерешительность Временное правительство помешала в июле 1917 г. подавить «большевистскую заразу» в зародыше [9, с. 149-151].

Затем Каринский оказался в Крыму, получив от Крымского земского краевого правительства должность прокурора судебной палаты. В связи с приближением к полуострову войск Красной Армии в апреле 1919 г. энергичный юрист стал «главноуполномоченным по эвакуации» Крыма [6]. Затем, оказавшись на территории, которую контролировал Верховный правитель Юга России А.И. Деникин, Каринский руководил обслуживающие его войска санитарными поездами Земгора. Можно предположить, что он проявил на этом поприще определенные организаторские способности, так как в начале 1920 г., на фоне общего развала управления тылом белых, произошел последний взлет его административной карьеры. Каринского, который состоял в тот момент уже в чине тайного советника, назначают гражданским начальником Черноморской губернии и управляющим Министерством внутренних дел Южно-Русского правительства при генерале А.И. Деникине [6].

Давний знакомый Каринского по Харькову В.Х. Даватц, в тот момент солдат-доброволец, записал в дневнике 7 марта 1920 г. о встрече с ним в Новороссийске 7 марта 1920 г.: «Я полетел к дому губернатора. Красивый дворец в стиле барокко выделялся из соседних домов. Я вошел на лестницу, ведущую в стеклянные двери. Как раз в это время Н.С. Каринский в сопровождении адъютанта вышел, чтобы сесть в автомобиль. Я едва узнал Николая Сергеевича, которого привык видеть в свободном пиджаке и, как он любил, в белых спортивных брюках. Теперь он величественно спускался по лестнице, одетый в серую шинель. На плечах блестели золотые погоны тайного советника. Во всей его фигуре видна генеральская солидность. Он остановился и подал мне руку. - Я хотел бы с Вами побеседовать, но Вы, вероятно, страшно заняты: Вы теперь в таких высоких чинах.... - Чин - это дело человеческое, - сказал Каринский. - Сегодня я действительно занят. Лучше всего приходите завтра сюда же, в час дня...» [4, с. 82-83].

Гражданская война завершилась для Каринского осенью 1920 г., когда он эвакуировался с остатками войск Врангеля в Константинополь. Там он стал председателем 
Совета присяжных поверенных, который действовал при российском Консульском суде, а также товарищем председателя Русского комитета, объединяющего деятельности около 80 общественных организаций эмигрантов [6]. Осенью 1923 г. Каринский из Константинополя перебрался за океан в Нью-Йорк. Здесь ему на шестом десятке лет пришлось перебрать массу занятий: «доковой артели грузчиком, рабочим на писчебумажной и ковровой фабриках, машинистом на машине для мойки посуды в отеле "Пенсильвания", затем кочегаром, санитаром в клинике, садовником в парке и т.д. ...» [6]. Ведя борьбу за выживание, Каринский и здесь не чуждался общественной деятельности в среде относительно немногочисленной тогда русской диаспоры в США. В 1923 г. он входил в число организаторов «Союза русской присяжной адвокатуры», а позднее - « Общества русских юристов», состоял в Русском национальном комитете в Нью-Йорке и несколько лет являлся членом «Центрального Правления» - выборного органа, объединявшего Русские национальные комитеты Нью-Йорка, Вашингтона, Сан-Франциско, Сиэтла и Кливленда [6, 28].

Сотрудничал Каринский и в русскоязычной печати, редактируя выходившие в Нью-Йорке газеты «Вечернюю почту» и «Русскую газету», которые закрылись во время экономического кризиса 1929 г. После этого бывший исполняющий обязанности министра работал преимущественно таксистом [6]. К этому времени одинокий пожилой человек начал осмысливать свой жизненный путь. С 1942 г. Каринский сотрудничал в издаваемой в Сан-Франциско «Русской жизни» [6]. На ее страницах появлялись его очерки о пережитом, которые в совокупности составили обширные по объему и содержанию мемуары.

Первую попытку создание воспоминаний Каринский предпринял еще по горячим следам недавних событий, напечатав в сборнике «Пережитое» статью об июльских событиях 1917 г. [24]. В Константинополе он подготовил и опубликовал в «Архиве русской революции» свои воспоминания об эвакуации Новороссийска в марте 1920 г. [8]. На склоне лет в США он значительно расширил свои мемуары. В воспоминаниях можно выделить три тематических раздела. Первый посвящен русскому суду дореволюционной эпохи. Второй связан с событиями революции 1917 г. и Гражданской войны. Отдельный тематический блок рассказывает о знакомствах и встречах деятелями культуры «Серебряного века». В конце жизни автор планировал издать воспоминания в виде отдельной книги и даже составил соответствующий план, но его смерть помешала осуществлению этого замысла. Вырезки газетных статей, собранные в объемистые папки, остались на хранении у его дочери Татьяны Каринской, а затем у внучки Галины Сейдель. В 2015-2018 гг. она по частям передала их своему родственнику С.С. Каринскому, живущему в России, что позволило начать работу по введению мемуарного наследия Н.С. Каринского в научный оборот.

\section{ЛИТЕРАТУРА}

1. Бонч-Бруевич В.Д. На боевых постах Февральской и Октябрьской революции. М.: Федерация, 1931. 404 с.

2. Гессен И.В. История русской адвокатуры: Адвокатура, общество и государство. Т. 1. М.: Юрист, 1997. 376 с.

3. Гуларян А.Б. Механизмы дестабилизации общественной ситуации на начальном этапе Первой российской революции // Ученые записки Орловского государственного университета. 2010. № 3. Ч. 1. С. $82-85$.

4. Даватц В.Х. На Москву. Париж: тип. Рирарховского, 1921. 116 с.

5. Карабчевский Н.П. Что глаза мои видели. Т. 2. Революция и Россия. М.: Директ-Медиа, 2014. 122 с.

6. Каринский Н. С. Автобиография, сентябрь 1947 г. // Личный архив С.С. Каринского.

7. Каринский Н. С. Краткая автобиография, август 1932 г. // Личный архив С.С. Каринского.

8. Каринский Н.С. Эпизод из эвакуации Новороссийска // Архив русской революции. Т. 12. Берлин: Слово, 1923. С. 149-156.

9. Михайловский Г.Н. Записки. Из истории российского внешнеполитического ведомства. Кн. 2. М.: Международные отношения, 1993. С. 149-151. 686 с.

10. Никитин Б.В. Роковые годы. СПб.: Питер, 2015. 320 с.

11. Новое время. 1910. 25 октября.

12. Оболенский В.А. Моя жизнь, мои современники. Париж: YMCA - PRESS, 1988. 753 с.

13. Отчет о деятельности Совета присяжных поверенных округа Харьковской судебной палаты за 1900-1901 г.: (С 15 -го февр. 1900 г. по 15-е февр. 1901 г.). Харьков: тип. Адольфа Дарре, 1901. 202 с.

14. Отчет о деятельности Совета присяжных поверенных округа Харьковской судебной палаты за 1902-1903 г.: (С 15 -го февр. 1902 г. по 15-е февр. 1903 г.). Харьков: тип. Адольфа Дарре, 1903. 240 с.

15. Отчет о деятельности Совета присяжных поверенных округа Харьковской судебной палаты за 1903-1904 г.: (С 15 -го февр. 1903 г. по 15-е февр. 1904 г.). Харьков: тип. Адольфа Дарре, 1904. 248 с.

16. Отчет о деятельности Совета присяжных поверенных округа Харьковской судебной палаты за 1904-1905 г.: (С 15 -го февр. 1904 г. по 15 -е февр. 1905 г.). Харьков: тип. Адольфа Дарре, 1905. 278 с.

17. Отчет о деятельности Совета присяжных поверенных округа Харьковской судебной палаты за 1905-1906 г.: (С 15 -го февр. 1905 г. по 15 -е февр. 1906 г.). 
Харьков: тип. Адольфа Дарре, 1906. 184 с.

18. Отчет о деятельности Совета присяжных поверенных округа Харьковской судебной палаты.. за 1906-1907 г.: (С 15 -го февр. 1906 г. по 15 -е февр. 1907 г.). Харьков: тип. Адольфа Дарре, 1907. 255 с.

19. Отчет о деятельности Совета присяжных поверенных округа Харьковской судебной палаты за 1907-1908 г.: (С 15 -го февр. 1907 г. по 15 -е февр. 1908 г.). Харьков: тип. Адольфа Дарре, 1908. 264 с.

20. Отчет о деятельности Совета присяжных поверенных округа Харьковской судебной палаты за 1908-1909 г.: (С 15 -го февр. 1908 г. по 15-е февр. 1909 г.). Харьков: тип. Адольфа Дарре, 1909. 382 с.

21. Отчет о деятельности Совета присяжных поверенных округа Харьковской судебной палаты за 1911-1912 г.: (С 15 -го февр. 1911 г. по 15 -е февр. 1912 г.). Харьков: тип. Адольфа Дарре, 1912.320 c.

22. Отчет о деятельности Совета присяжных поверенных округа Харьковской судебной палаты за 1912-1913 год: (С 15 -го февр. 1912 г. по 15 -е февр. 1913 г.). Харьков: тип. Адольфа Дарре, 1913. 439 с.

23. Отчет о деятельности Совета присяжных поверенных округа Харьковской судебной палаты за 1914-1915 год: (С 15 -го февр. 1914 г. по 15 -е февр. 1915 г.). Харьков: тип. Адольфа Дарре, 1915. 463 с. разд. паг.

24. Пережитое. Сборник. 1917-март 1918. М. [б. и.], 1918. 169 с.

25. Перес Б.С. Партийная работа в Орле (1902-1903 гг.) // Пролетарская революция. 1923. № 5. С. 260-270.

26. Рабинович А.Е. Кровавые дни. Июльское восстание 1917 года в Петрограде. М.: Республика, 1992. 276 с.

27. Российский государственный исторический архив. Ф. 1343. Оп. 23. Д. 1512.

28. Ручкин А.Б. Русская диаспора в Соединенных Штатах Америки в первой половине XX в. М.: Издательство Национального института бизнеса, 2006. 446 с.

29. Сборник в пользу недостаточных студентов Московского университета / Под ред. [и с предисл.] В.А. Гольцева. М.: типо-лит. т-ва И.Н. Кушнерев и Кㅜ 1897. IV. 220 C.

30. Следственное дело большевиков: Материалы Предварительного следствия о вооруженном выступлении 3-5 июля 1917 г. в г. Петрограде против государственной власти. Июль-октябрь 1917 г. Сборник документов: в 2 кн. Кн. 1 / под ред. О.К. Иванцовой. — М.: Российская политическая энциклопедия (РОССПЭН), 2012. 989 C.

31. Следственное дело большевиков: Материалы Предварительного следствия о вооруженном выступлении 3-5 июля 1917 г. в г. Петрограде против государственной власти. Июль-октябрь 1917 г. Сборник документов: в 2 кн. Кн.2. Ч.1 / под ред. 0.К. Иванцовой. - М. : Российская политическая энциклопедия (РОССПЭН), 2012.822 с.

32. Следственное дело большевиков: Материалы Предварительного следствия о вооруженном выступлении 3-5 июля 1917 г. в г. Петрограде против государственной власти. Июль-октябрь 1917 г. Сборник документов: в 2 кн. Кн.2. Ч.2 / под ред. О. К. Иванцовой. — М. : Российская политическая энциклопедия (РОССПЭН), 2012. $687 \mathrm{c}$.

33. Соболев Г.Л. Русская революция и «немецкое золото». СПб.: Нева, 2002. 479 с.

34. Центральный государственный архив города Москвы. Ф. 418. Оп. 307. Д. 357.

35. Центральный государственный архив города Москвы. Ф. 418. Оп. 77. Д. 2477.

( А Акульшин Петр Владимирович (stone2708@mail.ru).

Журнал «Современная наука: актуальные проблемы теории и практики» 